\title{
Rootstocks Affect Tree Growth, Yield, and Juice Quality of 'Marsh' Grapefruit
}

\author{
William S. Castle ${ }^{1}$ \\ Citrus Research and Education Center, Horticultural Sciences Department, \\ IFAS, University of Florida, 700 Experiment Station Road, Lake Alfred, FL \\ 33850
}

\author{
Kim D. Bowman \\ U.S. Horticultural Research Laboratory, ARS, U.S. Department of Agriculture, \\ 2001 S. Rock Road, Fort Pierce, FL 34945
}

James C. Baldwin, Jude W. Grosser, and Frederick G. Gmitter, Jr. Citrus Research and Education Center, Horticultural Sciences Department, IFAS, University of Florida, 700 Experiment Station Road, Lake Alfred, FL 33850

Additional index words. Citrange, citrumelo, mandarin rootstocks, Sunki mandarin hybrids, US-897, US-812

\begin{abstract}
Two adjacent rootstock trials were conducted in the east coast Indian River region of Florida with 'Marsh' grapefruit (Citrus paradisi Macf.) scion. The objective was to find rootstocks to replace sour orange $(C$. aurantium $\mathrm{L}$.) because of losses to citrus tristeza virus, and to replace Swingle citrumelo $[C$. paradisi $\times$ Poncirus trifoliata $(\mathrm{L}$.) $\mathrm{Raf}$. because of its limited usefulness in certain poorly drained coastal sites. The trials were conducted in randomized complete blocks with 12 single-tree replicates spaced $4.6 \times 6.9 \mathrm{~m}$. The soils were of the Wabasso and Riviera series. The first trial consisted largely of trees on citrange $[C$. sinensis $(\mathrm{L}$.) Osb. $\times P$. trifoliata $]$ and citrumelo rootstocks, 'Cipo' sweet orange (C. sinensis), and various hybrid rootstocks. The second trial involved mandarin rootstocks (C. reticulata Blanco) and sour orange and related rootstocks. Trees were grown for 7 years and yield and juice quality data were collected for the last 4 years of that period. Those rootstocks identified as the most promising, based on combinations of smaller tree size and high productivity and juice quality, were two Sunki mandarin $\times$ Swingle trifoliate orange (TF) hybrids (C-54, C-146), a Sunki mandarin $\times$ Flying Dragon TF hybrid, C-35 citrange, and a Cleopatra mandarin $\times$ Rubidoux TF hybrid $(\times 639)$. The trees on these five rootstocks cropped well leading to soluble solids (SS) values of 3000 to $4000 \mathrm{~kg} / \mathrm{ha}$ when they were 7-years old. The trees on C-54 and C-146 were relatively large, somewhat taller than trees on sour orange, whereas those on C-35 and the Sunki $\times$ Flying Dragon hybrid were smaller and similar to sour orange in tree height. Fruit quality among the trees on C-35 and the Sunki $\times$ Flying Dragon hybrid had relatively high SS concentration (better than sour orange), and the other three rootstocks had relatively lower solids concentration (poorer than sour orange). The trees on C-35 and the Sunki $\times$ Flying Dragon hybrid would be good candidates for higher density orchards.
\end{abstract}

Grapefruit has long been the major fresh fruit produced in Florida. For many years the seedless white cultivar 'Marsh' was the dominant selection. It has slowly been replaced by pigmented seedless selections like 'Redblush'

\footnotetext{
We are very grateful to personnel of the Becker Holding Company on whose property this work was conducted. We especially recognize Lynn Faulkner who at the time was the nursery manager and oversaw the considerable effort in propagating the trial trees and insuring their identification through to planting. We also extend our gratitude to Florida citrus growers who supported this work through a self-imposed tax for research funds granted by the Florida Citrus Production Research Advisory Council.

${ }^{1}$ To whom reprint requests should be addressed; e-mail bcastle@ufl.edu.
}

fruit (Fla. Agric. Stat. Serv., 2010). The second region is the southwest, also a largely coastal area and, third, the Central Florida Ridge, which runs along the center of the state and consists of well-drained sandy soils at elevations up to $100 \mathrm{~m}$.

The early reputation of Florida-grown grapefruit was established in the Indian River region where high external and internal quality were the result of particular climatic factors and the use of sour orange rootstock (Citrus aurantium L.). Fruit grown in this production region is often touted as the ideal because of their oblate shape with a smooth, thin skin, and excellent flavor. The use of sour orange rootstock for grapefruit was reduced for many years because of its susceptibility and considerable tree losses associated with quick decline strains of citrus tristeza disease caused by an aphid-transmitted virus (Stover and Castle, 2002). However, propagations with sour orange have increased recently because potential replacement rootstocks such as Smooth Flat Seville and Kinkoji have been explored commercially and proven to be of questionable usefulness mostly because fruit from trees on those two rootstocks often fail to meet minimum maturity standards particularly for SS concentration (Division Plant Industry, 2010; McCollum et al., 2002). As a result, a number of other rootstocks including Kuharske citrange, $\times 639$, and Swingle citrumelo were tried as replacements for sour orange. It was subsequently learned that trees on Swingle citrumelo were suited to only particular site conditions in the Indian River region (Bauer et al., 2005). Furthermore, much of the fruit grown in the Indian River is exported to Japan, where the quality standards set by the buyers are rigid and can exceed the U.S. standards (Fellers, 1990). Therefore, our objective was to conduct two rootstock trials to evaluate a broad range of commercial and new rootstocks available at the time. Special focus was given to identify the rootstocks that increased juice SS concentration, earliness of maturity, and reduced tree size.

\section{Materials and Methods}

Plant material and propagation. The commercial cooperator produced containergrown nursery trees in a company nursery. Seeds or seedlings of the rootstocks (Table 1) originating mostly from local sources were provided to the nursery manager for propagation with 'Marsh' grapefruit scion, clone F57-X-E, for which the budwood source had been tested for viruses and viroids and no citrus tristeza virus (CTV), xyloporosis (X), or exocortis (E) was detected.

Field trials. The grower cooperator provided a field site (lat. $27^{\circ} 04^{\prime} 19.55$; Long. $80^{\circ} 13^{\prime} 13.31$; elevation, $3.6 \mathrm{~m}$ ) west of Hobe Sound, FL, that had previously been planted with citrus. The soil series at the site is mapped as Wabasso sand, a Spodosol in the family of Alfic Haplaquods. The soil has a surface layer of black to gray sand $\approx 30$ $\mathrm{cm}$ thick underlain by 30 to $50 \mathrm{~cm}$ of light 
Table 1. Rootstocks in two 'Marsh' grapefruit trials, Hobe Sound, FL.

\begin{tabular}{|c|c|c|}
\hline Rootstock & Scientific name & Source $^{z}$ \\
\hline \multicolumn{3}{|l|}{ Experiment 1} \\
\hline Benton citrange & $\begin{array}{l}\text { Citrus sinensis }(\mathrm{L} .) \text { Osb. } \times \\
\quad \text { Poncirus trifoliata (L.) Raf. }\end{array}$ & DPI \\
\hline C-35 citrange & C. sinensis $\times P$. trifoliata & DPI \\
\hline Carrizo citrange & C. sinensis $\times P$. trifoliata & DPI \\
\hline Cipo sweet orange & C. sinensis & USDA \\
\hline Cohen citrange & C. sinensis $\times P$. trifoliata & DPI \\
\hline F80-2 citrumelo & C. paradisi Macf. $\times P$. trifoliata & DPI \\
\hline F80-5 citrumelo & C. paradisi $\times P$. trifoliata & DPI \\
\hline F80-6 citrumelo & C. paradisi $\times P$. trifoliata & DPI \\
\hline F80-7 citrumelo & C. paradisi $\times P$. trifoliata & DPI \\
\hline F80-8 citrumelo & C. paradisi $\times P$. trifoliata & DPI \\
\hline F80-9 citrumelo & C. paradisi $\times P$. trifoliata & DPI \\
\hline $\begin{array}{l}\text { Koethen sweet orange } \times \\
\quad \text { Rubidoux trifoliate orange }(\mathrm{TF})\end{array}$ & C. sinensis $\times P$. trifoliata & DPI \\
\hline Kuharske citrange & C. sinensis $\times P$. trifoliata & DPI \\
\hline Morton citrange & C. sinensis $\times P$. trifoliata & DPI \\
\hline Rangpur $\times$ Marks TF (1261) & C. limonia Osb. $\times$ P. trifoliata & LC $53-18-1$ \\
\hline Rangpur $\times$ Marks TF (1262) & C. limonia $\times P$. trifoliata & LC $53-19-1$ \\
\hline Rangpur $\times$ Swingle $\mathrm{TF}$ & C. limonia $\times P$. trifoliata & LC $53-16$ \\
\hline Rusk citrange & C. sinensis $\times P$. trifoliata & DPI \\
\hline Sacaton citrumelo & C. paradisi $\times P$. trifoliata & DPI \\
\hline $\begin{array}{l}\text { Sunki mandarin } \times \\
\text { Flying Dragon TF }\end{array}$ & C. reticulata Blanco $\times P$. trifoliata & LC $53-15$ \\
\hline $\begin{array}{l}\text { Sunki mandarin } \times \\
\text { Swingle TF }(C-146)\end{array}$ & C. reticulata $\times P$. trifoliata & LC 58-1 \\
\hline Swingle citrumelo & C. paradisi $\times P$. trifoliata & DPI \\
\hline Troyer citrange & C. sinensis $\times P$. trifoliata & DPI \\
\hline US-119 & Citrumelo $\times C$. sinensis 'Succory' & USDA \\
\hline US-802 Pummelo $\times$ TF & C. grandis $\mathrm{L} . \times P$. trifoliata & USDA \\
\hline $\begin{array}{l}\text { US-812 Sunki mandarin } \times \\
\text { Benecke TF }\end{array}$ & C. reticulata $\times P$. trifoliata & USDA \\
\hline $\begin{array}{l}\text { US-896 Cleopatra mandarin } \times \\
\text { TF }\end{array}$ & C. reticulata $\times P$. trifoliata & USDA \\
\hline $\begin{array}{l}\text { US-897 Cleopatra mandarin } \times \\
\text { Flying Dragon TF }\end{array}$ & C. reticulata $\times P$. trifoliata & USDA \\
\hline $\begin{array}{l}\text { US-1001 Changsha mandarin } \times \\
\text { Eng. Lg. TF }\end{array}$ & C. reticulata $\times P$. trifoliata & DPI \\
\hline Uvalde citrange & C. sinensis $\times P$. trifoliata & DPI \\
\hline Yuma citrange & C. sinensis $\times P$. trifoliata & DPI \\
\hline \multicolumn{3}{|l|}{ Experiment 2} \\
\hline Changsha mandarin & C. reticulata & DPI \\
\hline Chinotto sour orange & C. myrtifolia Raf. & DPI \\
\hline Cleopatra mandarin & C. reticulata & DPI \\
\hline $\begin{array}{l}\text { Cleoptra mandarin } \times \\
\text { Rubidoux TF (x639) }\end{array}$ & C. reticulata $\times P$. trifoliata & DPI \\
\hline Goutou & C. aurantium L. putative hybrid & DPI \\
\hline Kinkoji & C. obovoidea Hort ex. Tak. & DPI \\
\hline Shekwaska mandarin & C. reticulata & DPI \\
\hline Smooth Flat Seville & C. aurantium putative hybrid & DPI \\
\hline Sun Chu Sha mandarin & C. reticulata & DPI \\
\hline Sunki mandarin & C. reticulata & DPI \\
\hline $\begin{array}{l}\text { Sunki mandarin } \times \text { Swingle } \\
\text { TF }(C-54)\end{array}$ & C. reticulata $\times P$. trifoliata & LC $57-16$ \\
\hline Yuzu & C. ichangensis Swing. $\times$ C. reticulata & DPI \\
\hline Zhuluan & C. aurantium putative hybrid & DPI \\
\hline
\end{tabular}

brownish gray sand. The spodic horizon is $\approx 50$ to $55 \mathrm{~cm}$ below the soil surface and is generally $15-$ to $30-\mathrm{cm}$ thick. It is underlain by a clay horizon of fine sandy loam soil. Soils of the Wabasso series are among the better soils for growing citrus in the Indian River region (Bauer et al., 2007). The site was prepared by excavating perimeter drainage ditches and forming double-row beds on which the trees were planted. Such beds are in randomized complete blocks with 12 singletree replicates. We selected the larger than normal number of replicates and smaller plot size because of the known soil variability in Indian River sites. The trees were managed with a standard grove microsprinkler irrigation system, nitrogen applications totaling 160-180 kg/ha/year, and a pest management program appropriate for fresh fruit (Obreza and Morgan, 2008; Rogers et al., 2009).

Data collection and analysis. Tree height was measured periodically. Tree survival was recorded in 2004, 9 years after planting. Annual samples of 50-60 fruit were collected from each plot near the time of harvest. Juice was extracted and analyzed with standard commercial equipment at the Citrus Research and Education Center, Lake Alfred, FL (Wardowski et al., 1995). Fruit yield was measured annually with a commercial harvesting crew by placing fruit in standard containers holding $400 \mathrm{~kg}$ and recording volume. Data analyses were according to the experiment design with mean separation by the least significant difference test. Some variables were examined by simple linear correlation analysis at $P \leq 0.05^{*}, 0.01^{* *}$, or $0.001 * * *$.

\section{Results and Discussion}

Tree height and survival. Mean height of the trees in E.1 (citrange and citrumelo rootstocks) and in E.2 (sour orange and related selections as well as mandarin types) were virtually identical at ages 4 (2.3 vs. 2.4 $\mathrm{m})$ and 9 years (3.2 vs. $3.2 \mathrm{~m}$, respectively) (Tables 2 and 3). The tallest trees in E.1 were those on US-802 (3.8 m) (Table 2). They were significantly taller than those on any other rootstock except the Rangpur $\times$ Swingle TF hybrid in E.1 where the trees on most rootstocks were $\approx 3.0$ to $3.4 \mathrm{~m}$ tall. Those on US-896, US-897, and Sacaton citrumelo had heights $<3.0 \mathrm{~m}$ and the trees on Rusk citrange were the smallest $(2.4 \mathrm{~m})$. There were significant height differences among the trees in E.2 where the tallest ones were those on Kinkoji $(3.7 \mathrm{~m})$, the Cleopatra mandarin $\times$ Rubidoux TF hybrid $(\times 639)$ and Smooth Flat Seville $(3.6 \mathrm{~m})$ (Table 3). The shortest trees were on sour orange $(3.1 \mathrm{~m})$.

Tree survival on many rootstocks in both trials was $100 \%$ and that on most other rootstocks was between $80 \%$ and $100 \%$ (Tables 2 and 3). Those on Sacaton citrumelo, Yuzu, and Changsha mandarin developed thin canopies and an unthrifty appearance and had the poorest survival rates $(<70 \%)$. Tree decline and loss from CTV occurred among the trees on sour orange and Chinotto sour orange based on typical stem pitting symptoms apparent at the bud union.

Fruit yield. Cropping began among the trees on some rootstocks when they were 2years old and continued the following year. The cropping in the 2 nd year was typically 10 to 20 fruit per tree and was recorded, but not included in the cumulative yield. The precocious trees tended to be on those rootstocks with the highest cumulative yields at the end 
Table 2. Height and survival ( $n=12)$ of 'Marsh' grapefruit trees on various rootstocks (E.1) planted in 1995 at $4.6 \times 6.9 \mathrm{~m}$

\begin{tabular}{|c|c|c|c|}
\hline \multirow[b]{2}{*}{ Rootstock $^{z}$} & \multicolumn{2}{|c|}{ Tree ht $(\mathrm{m})$ at age } & \multirow[b]{2}{*}{ Survival $(\%)$} \\
\hline & $\overline{4 \mathrm{yr}}$ & $9 \mathrm{yr}$ & \\
\hline$\overline{\text { US-802 Pum. } \times \text { TF }}$ & 2.8 & 3.8 & 100 \\
\hline Rangpur $\times$ Swingle TF & 2.5 & 3.5 & 100 \\
\hline F80-7 citrumelo & 2.4 & 3.4 & 100 \\
\hline Sunki $\times$ Swingle TF $(C-146)$ & 2.5 & 3.4 & 100 \\
\hline Uvalde citrange & 2.7 & 3.4 & 100 \\
\hline Kuharske citrange & 2.4 & 3.4 & 100 \\
\hline Cohen citrange & 2.3 & 3.3 & 100 \\
\hline US-1001 Changsha $\times$ ELTF & 2.4 & 3.3 & 100 \\
\hline F80-6 citrumelo & 2.6 & 3.3 & 85 \\
\hline Rangpur $\times$ Marks TF $(1261)$ & 2.6 & 3.3 & 93 \\
\hline Carrizo citrange & 2.5 & 3.3 & 85 \\
\hline F80-9 citrumelo & 2.4 & 3.3 & 87 \\
\hline Swingle citrumelo & 2.5 & 3.2 & 100 \\
\hline US-812 Sunki $\times$ Benecke TF & 2.3 & 3.2 & 100 \\
\hline F80-2 citrumelo & 2.4 & 3.2 & 100 \\
\hline Benton citrange & 2.5 & 3.1 & 100 \\
\hline C-35 citrange & 2.4 & 3.1 & 100 \\
\hline Cipo sweet orange & 2.2 & 3.1 & 75 \\
\hline Koethen sweet orange $\times$ Rubidoux TF & 2.1 & 3.0 & 100 \\
\hline Morton citrange & 2.0 & 3.0 & 94 \\
\hline F80-8 citrumelo & 2.1 & 3.0 & 88 \\
\hline Sunki $\times$ Flying Dragon TF & 2.2 & 3.0 & 94 \\
\hline Sacaton citrumelo & 1.9 & 2.9 & 65 \\
\hline US- 897 Cleo $\times$ Flying Dragon TF & 2.0 & 2.7 & 92 \\
\hline US-896 Cleo $\times$ TF & 2.0 & 2.7 & 100 \\
\hline Rusk citrange & 1.9 & 2.4 & 77 \\
\hline F80-5 citrumelo ${ }^{y}$ & 2.5 & - & 100 \\
\hline Rangpur $\times$ Marks TF $(1262)^{\mathrm{y}}$ & 1.5 & - & 94 \\
\hline Troyer citrange ${ }^{\mathrm{y}}$ & 2.4 & - & 94 \\
\hline US-119y & 2.0 & - & 100 \\
\hline Yuma citrange $\mathrm{e}^{\mathrm{y}}$ & 2.3 & - & 100 \\
\hline Mean & 2.3 & 3.2 & - \\
\hline Least significant difference & 0.3 & 0.3 & - \\
\hline
\end{tabular}

${ }^{\mathrm{z}}$ Rootstocks are ranked by tree height at age 9 years.

${ }^{\mathrm{y}}$ Because of relatively poor yield and other performance factors, these trees were marked for removal after 7 years and data collection was discontinued.

Table 3. Height and survival $(n=12)$ of 'Marsh' grapefruit trees (E.2) on various rootstocks planted in 1995 at $4.6 \times 6.9 \mathrm{~m}$

\begin{tabular}{|c|c|c|c|}
\hline \multirow[b]{2}{*}{ Rootstock ${ }^{z}$} & \multicolumn{2}{|c|}{ Tree ht $(\mathrm{m})$ at age } & \multirow[b]{2}{*}{ Survival (\%) } \\
\hline & $\overline{4 \mathrm{yr}}$ & $9 \mathrm{yr}$ & \\
\hline Kinkoji & 2.7 & 3.7 & 100 \\
\hline Smooth Flat Seville & 2.5 & 3.6 & 92 \\
\hline $\begin{array}{l}\text { Cleopatra mandarin } \times \text { Rubidoux } \\
\text { TF }(\times 639)\end{array}$ & 2.6 & 3.6 & 100 \\
\hline Goutou & 2.4 & 3.5 & 100 \\
\hline Sun Chu Sha mandarin & 2.5 & 3.5 & 100 \\
\hline Cleopatra mandarin & 2.4 & 3.4 & 79 \\
\hline Sunki $\times$ Swingle TF $(C-54)$ & 2.5 & 3.3 & 100 \\
\hline Sunki mandarin & 2.4 & 3.3 & 78 \\
\hline Zhuluan & 2.2 & 3.2 & 95 \\
\hline Shekwasha mandarin & 2.1 & 3.2 & 93 \\
\hline Sour orange & 2.3 & 3.1 & 83 \\
\hline Changsha mandarin ${ }^{\mathrm{y}}$ & 2.1 & - & 75 \\
\hline Chinotto sour orange $\mathrm{e}^{\mathrm{y}}$ & 2.6 & - & 67 \\
\hline Yuzu $^{y}$ & 1.9 & - & 61 \\
\hline Mean & 2.4 & 3.4 & - \\
\hline Least significant difference & 0.4 & 0.3 & - \\
\hline
\end{tabular}

${ }^{2}$ Rootstocks are ranked by tree height at age 9 years.

${ }^{y}$ Trees were either removed or data collection was discontinued because of poor survival, low yield or citrus tristeza virus as with Chinotto sour orange.

of the experiments such as Uvalde and C-35 citranges and Sunki $\times$ Swingle TF $(\mathrm{C}-146$; C-54). The early bearing also explained the high yield among those rootstocks when yield was first measured across all rootstocks at tree age 4 years (Tables 4 and 5). In the first-year of measurement, mean yield across all rootstocks was 51 and $44 \mathrm{~kg} /$ tree for E. 1 and E.2, respectively. Yield increased to $122 \mathrm{~kg} /$ tree (E.1) or $148 \mathrm{~kg} /$ tree (E.2) when the trees were 7 -years old. The yield data were more variable than desired because of site variability. As a result, there were fewer differences among rootstocks than we experienced in other Florida field trials. Nevertheless, the trees on the highest yielding rootstocks significantly exceeded the yields of the trees on many other rootstocks throughout the measurement period. Some of the lowest yielding trees were those on US-896, US119, Cipo sweet orange, Koethen $\times$ Rubidoux TF citrange, F80-8 citrumelo, Yuzu, Chinotto sour orange, and Changsha mandarin partly because of smaller tree height in many instances.

Yield at tree age 4 years was correlated to yield at tree age 7 years $\left(r=0.55^{*}\right.$, E. $1 ; r=$ $0.75^{* *}$ E.2) indicating that the trend established in the first commercial crop was continued for three additional years. Some of the variability that led to the lower correlation in E.1 was the smaller first-year yields of the trees on Yuma and Troyer citranges and F80 5 citrumelo followed by large yields at tree age 7 years, and declining yields of the trees on US-119 and Rangpur $\times$ Marks TF (1262) as those trees aged. In E.2, there were no decreases in yield, but the trees on Goutou increased more so than the trees on the other rootstocks.

There were significant differences in yield among rootstocks in each year leading to 4 year cumulative yields that ranged from only 59 to $596 \mathrm{~kg} /$ tree in E.1, a 10-fold difference, and 207 to $719 \mathrm{~kg} /$ tree in E.2 (Tables 4 and $5)$. Trees on the most productive rootstocks had cumulative yields $>500 \mathrm{~kg} /$ tree. They were the most productive rootstocks primarily because their yield generally increased each year unlike the trees on many of the other rootstocks, which tended to alternate crop. The trees with the highest cumulative yield, $719 \mathrm{~kg} /$ tree, were those on Sunki $\times$ Swingle TF (C-54).

The relationship between cumulative yield and tree height was weakly evident in E.1 ( $r=$ $\left.0.40^{*}\right)$ and not at all in E.2 $(r=0.05 \mathrm{~ns})$. That is a result of there being a full range of tree height and yield combinations. For example, there were high yielding, smaller trees such as those on C-35 citrange, Sunki $\times$ Swingle TF (C-54), and Sunki $\times$ Flying Dragon TF; high yielding, taller trees like those on Uvalde citrange and $\times 639$ hybrid, and low yielding short or tall trees.

Fruit weight, juice quality, SS production. Fruit diameters (sizes) and their distribution are important variables with grapefruit because the fruit is primarily grown for the fresh market. Neither variable was measured in our trials. Instead, the mean weight of the fruit in the juice samples collected each year was recorded and is used herein as a general measure of fruit size. Those values represent only a portion of the tree crop although, in sampling, we attempted to collect fruit that were typical of the entire crop on each tree. Also, the juice samples were collected by several individuals who introduced some variability into the sampling. Fruit size is inversely related to crop size, a relationship not well documented for grapefruit (Barry et al., 2004; Zamski and Schaffer, 1996). Thus, we consider fruit weight as only a coarse estimation subject to the preceding limitations.

Fruit weight was larger at tree age 4 years than 7 years regardless of rootstock (Tables 6 
Table 4. Yield ( $\mathrm{kg} /$ tree; $n=6$ ) of 'Marsh' grapefruit trees on various rootstocks (E.1) planted in 1995 at $4.6 \times 6.9 \mathrm{~m}$

\begin{tabular}{|c|c|c|c|c|c|}
\hline \multirow[b]{2}{*}{ Rootstock } & \multicolumn{4}{|c|}{ Tree age (yr) } & \multirow{2}{*}{$\begin{array}{c}\text { Cumulative } \\
\text { yield }\end{array}$} \\
\hline & 4 & 5 & 6 & 7 & \\
\hline Uvalde citrange & 75 & 121 & 201 & 200 & 596 \\
\hline C-35 citrange & 94 & 190 & 110 & 178 & 573 \\
\hline Sunki $\times$ Swingle TF $(C-146)$ & 74 & 123 & 146 & 207 & 550 \\
\hline Sunki $\times$ Flying Dragon TF & 64 & 134 & 151 & 186 & 535 \\
\hline Rangpur $\times$ Marks TF (1261) & 48 & 134 & 183 & 169 & 534 \\
\hline Carrizo citrange & 59 & 139 & 169 & 140 & 506 \\
\hline F80-9 citrumelo & 59 & 113 & 140 & 183 & 495 \\
\hline Morton citrange & 53 & 133 & 185 & 122 & 493 \\
\hline US-812 Sunki $\times$ Benecke TF & 63 & 70 & 133 & 178 & 444 \\
\hline Rangpur $\times$ Swingle TF & 67 & 108 & 166 & 101 & 442 \\
\hline US-802 Pum. $\times$ TF & 27 & 180 & 96 & 135 & 438 \\
\hline Benton citrange & 71 & 113 & 121 & 121 & 425 \\
\hline F80-6 citrumelo & 44 & 121 & 144 & 116 & 423 \\
\hline Swingle citrumelo & 51 & 119 & 123 & 130 & 422 \\
\hline Sacaton citrumelo & 28 & 113 & 137 & 138 & 417 \\
\hline Kuharske citrange & 49 & 128 & 106 & 111 & 394 \\
\hline Yuma citrange & 32 & 144 & 112 & 99 & 386 \\
\hline Troyer citrange & 48 & 129 & 62 & 140 & 378 \\
\hline F80-8 citrumelo & 64 & 118 & 87 & 106 & 375 \\
\hline US-1001 Changsha $\times$ ELTF & 52 & 83 & 130 & 106 & 370 \\
\hline F80-2 citrumelo & 35 & 123 & 80 & 109 & 348 \\
\hline F80-7 citrumelo & 48 & 113 & 85 & 101 & 347 \\
\hline F80-5 citrumelo & 35 & 82 & 92 & 106 & 314 \\
\hline US-897 Cleo $\times$ Flying Dragon TF & 62 & 87 & 73 & 86 & 308 \\
\hline Cipo sweet orange & 48 & 36 & 126 & 92 & 301 \\
\hline Rusk citrange & 59 & 108 & 21 & 101 & 289 \\
\hline Cohen citrange & 21 & 51 & 118 & 97 & 287 \\
\hline Koethen sweet orange $\times$ Rubidoux TF & 47 & 77 & 70 & 92 & 285 \\
\hline US-896 Cleopatra mandarin $\times \mathrm{TF}$ & 44 & 46 & 76 & 87 & 253 \\
\hline US-119 hybrid & 44 & 67 & 60 & 44 & 215 \\
\hline Rangpur × Marks TF (1262) & 29 & 3 & 14 & 13 & 59 \\
\hline Mean & 51 & 107 & 114 & 122 & 394 \\
\hline Least significant difference & 24 & 83 & 113 & 84 & - \\
\hline
\end{tabular}

Table 5. Yield (kg/tree; $n=6$ ) of 'Marsh' grapefruit trees (E.2) on various rootstocks planted in 1995 at $4.6 \times 6.9 \mathrm{~m}$.

\begin{tabular}{lcrrrc}
\hline & \multicolumn{4}{c}{ Tree age (yr) } & Cumulative \\
\cline { 2 - 5 } Rootstock & 4 & 5 & 6 & 7 & yield \\
\hline Sunki $\times$ Swingle TF $($ C-54) & 80 & 175 & 202 & 262 & 719 \\
Cleopatra $\times$ Rubidoux TF $(\times 639)$ & 81 & 134 & 207 & 247 & 669 \\
Sunki mandarin & 58 & 166 & 183 & 180 & 587 \\
Sour orange & 65 & 141 & 172 & 169 & 547 \\
Kinkoji & 33 & 128 & 183 & 149 & 493 \\
Sun Chu Sha mandarin & 42 & 98 & 183 & 166 & 489 \\
Cleopatra mandarin & 35 & 121 & 152 & 149 & 457 \\
Goutou & 22 & 121 & 129 & 162 & 434 \\
Smooth Flat Seville & 35 & 136 & 127 & 106 & 404 \\
Zhuluan & 34 & 83 & 103 & 129 & 349 \\
Shekwasha mandarin & 30 & 90 & 111 & 100 & 331 \\
Changsha mandarin & 35 & 65 & 84 & 104 & 288 \\
Chinotto sour orange & 27 & 90 & 119 & 39 & 275 \\
Yuzu & 31 & 33 & 61 & 82 & 207 \\
Mean & 44 & 113 & 148 & 148 & 446 \\
Least significant difference & 24 & 63 & 65 & 84 & - \\
\hline
\end{tabular}

and 7). Young grapefruit trees when they begin cropping tend to have relatively large fruit partly because smaller crops often lead to larger sizes. At tree age 7 years, mean fruit weight was $430 \mathrm{~g}$ in E.1 and $420 \mathrm{~g}$ in E.2. There were almost no significant differences among rootstocks in either trial. Trees with fruit $\geq 470$ g included those on Yuma, Benton, Cohen and Morton citranges, and Kinkoji. Fruit weight was not significantly correlated with yield $(r=0.16 \mathrm{~ns})$ in either year suggesting that fruit size was more an expression of other factors than a direct influence of rootstock. Nevertheless, the most productive trees had fruit with weights below the mean with the notable exception of the larger fruit on the trees on Uvalde citrange (490 g). Trees on mandarin rootstocks like Cleopatra, Sun Chu Sha, and Sunki are well-known for producing fruit with smaller sizes, but that was not the case in these trials (Castle, 1987).

Grapefruit shipped for the fresh market from Florida and those that are processed must meet minimum maturity standards that change seasonally for juice content according to fruit size, and SS concentration and SS : acid ratio (Wardowski et al., 1995). Our juice content data are means for the fruit samples and do not relate to the standards for individual fruit sizes. However, using the mean fruit weight in our trials and the required juice content of $230 \mathrm{ml}$ for a typical commercial fruit size, juice content would be $\approx 53 \%$ assuming $1 \mathrm{ml}$ of juice weighs $\approx 1 \mathrm{~g}$. Thus, the mean juice contents (by weight) and those for the fruit from the trees on most rootstocks in E1 and E.2 were in the commercially acceptable range (Tables 6 and 7). There were no differences among most rootstocks, but fruit from the trees on Sunki $\times$ Flying Dragon TF, US-896, and US-897 had values $>60 \%$ when the trees were 7 -years old as compared with fruit with juice contents $<55 \%$ among trees on US-802, Smooth Flat Seville, Kinkoji, Cleopatra mandarin, and Benton, Morton, and Yuma citranges.

The trial fruit were sampled in late January to late February at which time a minimum of $7.0 \% \mathrm{SS}$ concentration is required in Florida (Wardowski et al., 1995). The mean SS concentrations were $\geq 8.0 \%$ in the E. 1 trees when they were 4- and 7-years old and in the trees in E. 2 when they were 7-years old (Tables 6 and 7). Values $\geq 9.0 \%$ occurred among the trees on 13 rootstocks in E.1 and E.2 combined and included several with values as high as $9.3 \%$ (C-35, Kuharske and Rusk citranges, Cipo sweet orange, and Yuzu) at tree age 7 years. Fruit from the trees on US-802, a pummelo hybrid, had low values in both years. The juice acid values varied significantly among rootstocks, but the values were within the normal range for commercial fruit (Fla. Agri. Stat. Serv., 2010). The SS : acid ratio minimum standards for fresh fruit are a sliding scale of values depending on SS concentration. As it increases from 8.1 to 9.5 , the minimum ratio decreases from 7.0 to 6.8. All fruit from E.1 and E. 2 in both years exceeded those values. There were significant differences among rootstocks and, in most instances, the higher ratios were associated with those rootstocks yielding fruit with the higher SS concentrations (Tables 6 and 7).

The quantity of SS per hectare is a common measurement for oranges that are processed, but is also meaningful with Florida grapefruit, which are normally grown for the fresh market. However, $\approx 50 \%$ of the grapefruit crop is processed each year. Soluble solids per hectare is a calculation that integrates fruit yield with juice quality. At tree age 7 years, the values ranged from $4096 \mathrm{~kg} / \mathrm{ha}$ [Sunki $\times$ Swingle TF (C-54)] to $248 \mathrm{~kg} / \mathrm{ha}$ [Rangpur $\times$ Marks TF (1262)] across both trials (Tables 6 and 7). Soluble solids per hectare and yield were very highly correlated $\left(r=0.96^{* * *}\right)$ at tree age 7 years illustrating the importance of fruit yield. At that tree age in E.1, fruit from the trees on Sunki $\times$ Flying Dragon TF had a high juice content and SS concentration along with a high fruit yield leading to the highest value for SS per hectare. Some of the trees on the rootstocks with the next 
Table 6. Juice quality and fruit weight $(n=4)$ of fruit harvested from 'Marsh' grapefruit trees (E.1) on various rootstocks planted in $1995 .^{\mathrm{z}}$

\begin{tabular}{|c|c|c|c|c|c|c|c|}
\hline Rootstock & $\begin{array}{l}\text { Tree } \\
\text { age } \\
\text { (yr) }\end{array}$ & $\begin{array}{l}\text { Fruit } \\
\text { wt }(g)^{y}\end{array}$ & $\begin{array}{c}\text { Juice } \\
\text { content } \\
(\%)\end{array}$ & $\begin{array}{l}\text { SS concn } \\
(\%)\end{array}$ & $\begin{array}{c}\text { Acid } \\
(\%)\end{array}$ & $\begin{array}{l}\text { SS/Acid } \\
\text { ratio }\end{array}$ & $\underset{(\mathrm{kg} / \mathrm{ha})^{\mathrm{x}}}{\mathrm{SS}}$ \\
\hline \multirow[t]{2}{*}{ Sunki $\times$ Flying Dragon TF } & 4 & 430 & 64.2 & 8.4 & 0.93 & 9.0 & 1638 \\
\hline & 7 & 400 & 60.7 & 9.2 & 0.91 & 10.1 & 3363 \\
\hline \multirow[t]{2}{*}{ Sunki $\times$ Swingle TF $(\mathrm{C}-146)$} & 4 & 560 & 56.7 & 7.6 & 0.96 & 8.0 & 899 \\
\hline & 7 & 430 & 56.7 & 8.5 & 0.86 & 9.9 & 3194 \\
\hline \multirow[t]{2}{*}{ Uvalde citrange } & 4 & 460 & 59.9 & 8.7 & 0.95 & 9.1 & 1759 \\
\hline & 7 & 490 & 56.6 & 8.8 & 0.92 & 9.6 & 3176 \\
\hline \multirow{2}{*}{ F80-9 citrumelo } & 4 & 500 & 57.9 & 8.3 & 0.97 & 8.5 & 803 \\
\hline & 7 & 430 & 57.5 & 9.1 & 0.87 & 10.4 & 2999 \\
\hline \multirow[t]{2}{*}{ US-812 Sunki $\times$ Benecke TF } & 4 & 460 & 60.8 & 8.6 & 0.93 & 9.3 & 999 \\
\hline & 7 & 420 & 58.7 & 8.7 & 0.84 & 10.4 & 2912 \\
\hline \multirow[t]{2}{*}{ C-35 citrange } & 4 & 540 & 56.5 & 8.4 & 0.95 & 8.8 & 1861 \\
\hline & 7 & 400 & 58.5 & 9.3 & 0.91 & 10.2 & 2791 \\
\hline \multirow[t]{2}{*}{ Rangpur $\times$ Marks TF (1261) } & 4 & 470 & 56.3 & 7.8 & 0.88 & 9.0 & 1146 \\
\hline & 7 & 440 & 55.1 & 8.6 & 0.82 & 10.5 & 2503 \\
\hline \multirow[t]{2}{*}{ Carrizo citrange } & 4 & 560 & 54.1 & 7.8 & 0.88 & 8.8 & 1227 \\
\hline & 7 & 450 & 56.1 & 8.8 & 0.85 & 10.3 & 2213 \\
\hline \multirow[t]{2}{*}{ Troyer citrange } & 4 & 580 & 53.0 & 7.4 & 0.92 & 8.0 & 544 \\
\hline & 7 & 430 & 55.8 & 8.8 & 0.85 & 10.4 & 2154 \\
\hline \multirow[t]{2}{*}{ Rangpur $\times$ Swingle TF } & 4 & 510 & 57.2 & 7.9 & 0.93 & 8.4 & 1135 \\
\hline & 7 & 420 & 55.6 & 8.4 & 0.90 & 9.3 & 2077 \\
\hline \multirow[t]{2}{*}{ Swingle citrumelo } & 4 & 560 & 57.0 & 7.6 & 0.95 & 8.0 & 922 \\
\hline & 7 & 410 & 57.5 & 8.7 & 0.88 & 9.9 & 2049 \\
\hline \multirow{2}{*}{ Sacaton citrumelo } & 4 & 470 & 57.3 & 8.1 & 0.91 & 8.9 & 871 \\
\hline & 7 & 420 & 55.8 & 8.6 & 0.86 & 10.0 & 2041 \\
\hline Benton citrange & 4 & 550 & 58.1 & 8.2 & 0.89 & 9.2 & 1444 \\
\hline & 7 & 470 & 54.5 & 9.1 & 0.85 & 10.8 & 1925 \\
\hline Morton citrange & 4 & 440 & 61.6 & 8.4 & 0.96 & 8.8 & 967 \\
\hline & 7 & 470 & 54.9 & 8.9 & 0.87 & 10.3 & 1907 \\
\hline Rusk citrange & 4 & 470 & 65.6 & 8.5 & 0.87 & 9.8 & 1259 \\
\hline & 7 & 330 & 59.8 & 9.3 & 0.89 & 10.5 & 1820 \\
\hline Yuma citrange & 4 & 530 & 54.3 & 8.1 & 1.01 & 8.1 & 185 \\
\hline & 7 & 500 & 51.2 & 8.6 & 0.89 & 9.6 & 1747 \\
\hline US-802 Pum. $\times$ TF & 4 & 500 & 52.7 & 7.1 & 0.95 & 7.5 & 576 \\
\hline & 7 & 520 & 50.9 & 7.8 & 0.87 & 9.0 & 1733 \\
\hline F80-8 citrumelo & 4 & 460 & 63.4 & 8.3 & 0.91 & 9.1 & 1160 \\
\hline & 7 & 370 & 57.1 & 9.3 & 0.81 & 11.4 & 1729 \\
\hline Kuharske citrange & 4 & 490 & 55.2 & 7.9 & 0.90 & 8.8 & 1085 \\
\hline & 7 & 460 & 54.8 & 8.5 & 0.83 & 10.2 & 1684 \\
\hline F80-2 citrumelo & 4 & 520 & 56.5 & 7.9 & 0.97 & 8.2 & 535 \\
\hline & 7 & 420 & 56.0 & 8.2 & 0.85 & 9.6 & 1647 \\
\hline F80-6 citrumelo & 4 & 480 & 58.1 & 7.7 & 0.95 & 8.2 & 1023 \\
\hline & 7 & 440 & 54.3 & 8.3 & 0.86 & 9.7 & 1612 \\
\hline US-897 Cleopatra mandarin $\times$ & 4 & 410 & 59.5 & 8.6 & 1.00 & 8.7 & 873 \\
\hline Flying Dragon TF & 7 & 340 & 63.1 & 9.1 & 0.91 & 9.9 & 1579 \\
\hline US-1001 Changsha mandarin $x$ & 4 & 510 & 55.8 & 7.2 & 0.93 & 7.8 & 692 \\
\hline ELTF & 7 & 480 & 51.9 & 8.1 & 0.88 & 9.2 & 1567 \\
\hline US-896 Cleopatra mandarin $\times \mathrm{TF}$ & 4 & 420 & 59.5 & 8.3 & 0.95 & 8.7 & 672 \\
\hline & 7 & 360 & 63.0 & 8.9 & 0.83 & 10.8 & 1562 \\
\hline Cipo sweet orange & 4 & 620 & 52.9 & 7.9 & 0.88 & 9.0 & 880 \\
\hline & 7 & 320 & 60.9 & 9.5 & 0.85 & 11.2 & 1518 \\
\hline Cohen citrange & 4 & 520 & 55.6 & 7.4 & 0.92 & 8.0 & 569 \\
\hline & 7 & 480 & 53.8 & 8.5 & 0.92 & 9.3 & 1447 \\
\hline Koethen sweet orange $x$ & 4 & 560 & 53.7 & 8.3 & 0.89 & 9.3 & 839 \\
\hline Rubidoux TF & 7 & 420 & 58.8 & 9.0 & 0.84 & 10.7 & 1546 \\
\hline F80-5 citrumelo & 4 & 530 & 53.5 & 7.7 & 0.96 & 8.0 & 291 \\
\hline & 7 & 460 & 53.3 & 8.5 & 0.82 & 10.3 & 1500 \\
\hline F80-7 citrumelo & 4 & 500 & 54.9 & 7.9 & 0.94 & 8.4 & 911 \\
\hline & 7 & 470 & 54.2 & 8.5 & 0.88 & 9.7 & 1485 \\
\hline US-119 & 4 & 410 & 62.8 & 8.8 & 1.03 & 8.6 & 1113 \\
\hline & 7 & 390 & 59.5 & 9.2 & 0.96 & 9.5 & 762 \\
\hline Rangpur × Marks TF (1262) & 4 & 510 & 56.4 & 7.7 & 0.90 & 8.6 & 311 \\
\hline & 7 & 450 & 56.8 & 8.5 & 0.83 & 10.3 & 248 \\
\hline Mean & 4 & 500 & 57.5 & 8.0 & 0.93 & 8.6 & 942 \\
\hline & 7 & 430 & 56.6 & 8.8 & 0.87 & 10.1 & 1953 \\
\hline Least significant difference & 4 & 120 & 6.7 & 0.8 & 0.07 & 1.0 & 792 \\
\hline & 7 & 150 & 3.5 & 0.6 & 0.06 & 0.9 & 1276 \\
\hline
\end{tabular}

${ }^{\mathrm{z}}$ Fruit samples collected 25 Feb. 2000 (tree age 4 years) and 29 Jan. 2003 (age 7 years). Data are sorted by soluble solids (SS) per hectare, tree age 7 years. Rootstocks sorted by soluble solids/ha, tree age 7 years. ${ }^{\mathrm{y}}$ Determined from the fruit sample collected for juice analysis.

${ }^{\mathrm{x}}$ Calculated as fruit yield/ha $(\mathrm{wt}) \times \%$ juice $\times \mathrm{SS}$ concentration. highest quantities of SS per hectare such as Sunki $\times$ Swingle TF (C-146) had significantly lower SS concentrations, but among the highest fruit yields leading to large quantities of high SS per hectare. Likewise in E.2, the trees on the two rootstocks with the highest values, Sunki $\times$ Swingle $(\mathrm{C}-54)$ and Cleopatra mandarin $\times$ Rubidoux TF $(\times 639)$, had below average juice SS concentrations, but high juice contents and fruit yields.

The most successful rootstock in Florida for fresh-market grapefruit has been sour orange for trees grown in the well-known Indian River district in the coastal flatwoods of the east coast. Several rootstocks in our trials have considerable promise as replacements for sour orange.

Comparative performance among citrange and citrumelo rootstocks. One purpose of our trials was to compare rootstocks within groups, e.g., citranges, citrumelos, mandarins, sour oranges, sour orange types, and others. We assembled as many members of each group as practical for evaluation because such comparisons are uncommon. Among the citranges in E.1, Uvalde and C-35 citranges ranked among the best performing rootstocks. On the basis of our trial results, both rootstocks would be deemed promising. However, they illustrate an important point about performance consistency as a prominent factor leading to commercial acceptance (Castle, 2010). C-35 citrange was developed and tested in California (Cameron and Soost, 1986; Kupper et al., 1994; Roose, 1996). Additional trials in many parts of the world led to commercialization including in Florida [M. Roose (CA) and growers in Australia, Dominican Republic, and Mexico, personal communication]. The high performance level of trees in our trial and other Florida trials with C-35 illustrate its promise as a rootstock for Florida citrus compared with all the citrange rootstocks tested (McCoy et al., 2004). Uvalde citrange is an old rootstock that has been tested for many years with inconsistent results (Castle, 1987; Castle and Baldwin, 2010; Wutscher, 1979). Thus, Uvalde citrange never received commercial interest and is not grouped with the overall promising rootstocks in our trials. Likewise with Morton citrange that was almost always the second best performing rootstock behind Swingle citrumelo in grapefruit trials conducted in Texas (Wutscher, 1979), but was an average rootstock in our trials. Its commercial adoption has been further hindered by a lack of seed production.

Other citranges such as Carrizo and Troyer were in the middle of the rankings, which may explain why they are not popular for use with grapefruit scions in the Florida coastal flatwoods (Stover and Castle, 2002). Various scions on Koethen sweet orange $\times$ Rubidoux TF have been under evaluation in Florida for many years, but smaller tree size has limited commercial adoption. Trees on $\mathrm{K} \times \mathrm{R}$ citrange are comparable to $\mathrm{C}-35$ citrange in tree height and juice quality (Castle and Phillips, 1980). In Florida trials, tree losses from blight or Phytophthora foot and root rots have been 
Table 7. Fruit weight and juice quality $(n=4)$ of fruit harvested from 'Marsh' grapefruit trees (E.2) on various rootstocks planted in $1995 .^{\mathrm{z}}$

\begin{tabular}{|c|c|c|c|c|c|c|c|}
\hline Rootstock & $\begin{array}{l}\text { Tree } \\
\text { age } \\
\text { (yr) }\end{array}$ & $\begin{array}{l}\text { Fruit } \\
\text { wt }(g)^{y}\end{array}$ & $\begin{array}{c}\text { Juice } \\
\text { content } \\
(\%)\end{array}$ & $\begin{array}{l}\text { SS concn } \\
(\%)\end{array}$ & $\begin{array}{l}\text { Acid } \\
(\%)\end{array}$ & $\begin{array}{l}\text { SS/Acid } \\
\text { ratio }\end{array}$ & $\begin{array}{c}\mathrm{SS} \\
(\mathrm{kg} / \mathrm{ha})^{\mathrm{x}}\end{array}$ \\
\hline \multirow[t]{2}{*}{ Sunki $\times$ Swingle TF (C-54) } & 4 & 460 & 59.8 & 7.8 & 0.90 & 8.7 & 1601 \\
\hline & 7 & 410 & 59.8 & 8.5 & 0.87 & 9.8 & 4096 \\
\hline \multirow{2}{*}{$\begin{array}{l}\text { Cleopatra mandarin } \times \\
\text { Rubidoux TF }(\times 639)\end{array}$} & 4 & 480 & 59.6 & 7.6 & 0.93 & 8.2 & 1677 \\
\hline & 7 & 430 & 56.0 & 8.1 & 0.90 & 9.0 & 4054 \\
\hline \multirow[t]{2}{*}{ Sunki mandarin } & 4 & 530 & 56.6 & 8.3 & 1.00 & 8.3 & 1225 \\
\hline & 7 & 420 & 56.0 & 9.1 & 0.98 & 9.2 & 3023 \\
\hline \multirow[t]{2}{*}{ Yuzu } & 4 & 540 & 56.4 & 8.0 & 0.94 & 8.5 & 855 \\
\hline & 7 & 380 & 60.8 & 9.3 & 0.91 & 10.2 & 2744 \\
\hline \multirow[t]{2}{*}{ Sun Chu Sha mandarin } & 4 & 560 & 55.4 & 7.7 & 0.98 & 7.9 & 918 \\
\hline & 7 & 400 & 58.9 & 8.8 & 0.86 & 10.2 & 2568 \\
\hline \multirow[t]{2}{*}{ Sour orange } & 4 & 420 & 59.8 & 8.2 & 0.96 & 8.6 & 1203 \\
\hline & 7 & 400 & 57.0 & 8.7 & 0.95 & 9.2 & 2317 \\
\hline \multirow[t]{2}{*}{ Cleopatra mandarin } & 4 & 540 & 52.4 & 7.3 & 0.96 & 7.6 & 474 \\
\hline & 7 & 410 & 54.4 & 8.3 & 0.94 & 8.9 & 2159 \\
\hline \multirow[t]{2}{*}{ Zhuluan } & 4 & 470 & 55.5 & 8.2 & 0.97 & 8.5 & 759 \\
\hline & 7 & 420 & 56.1 & 8.5 & 0.94 & 9.1 & 1714 \\
\hline \multirow[t]{2}{*}{ Kinkoji } & 4 & 560 & 52.1 & 7.6 & 0.99 & 7.7 & 425 \\
\hline & 7 & 480 & 52.3 & 8.4 & 0.92 & 9.1 & 1639 \\
\hline \multirow[t]{2}{*}{ Goutou } & 4 & 550 & 51.5 & 6.9 & 0.95 & 7.3 & 233 \\
\hline & 7 & 430 & 53.5 & 8.2 & 0.87 & 9.4 & 1587 \\
\hline \multirow[t]{2}{*}{ Changsha mandarin } & 4 & 500 & 58.5 & 7.6 & 0.91 & 8.4 & 651 \\
\hline & 7 & 420 & 54.5 & 9.1 & 0.99 & 9.2 & 1469 \\
\hline \multirow[t]{2}{*}{ Shekwasha mandarin } & 4 & 510 & 54.2 & 7.6 & 0.94 & 8.2 & 765 \\
\hline & 7 & 440 & 53.2 & 8.6 & 0.98 & 8.9 & 1409 \\
\hline \multirow[t]{2}{*}{ Smooth Flat Seville } & 4 & 500 & 54.1 & 7.1 & 0.92 & 7.8 & 474 \\
\hline & 7 & 460 & 51.8 & 8.2 & 0.92 & 9.0 & 915 \\
\hline \multirow[t]{2}{*}{ Chinotto sour orange } & 4 & 470 & 56.2 & 8.3 & 1.00 & 8.3 & 1048 \\
\hline & 7 & 400 & 56.1 & 8.8 & 0.96 & 9.2 & 670 \\
\hline \multirow[t]{2}{*}{ Mean } & 4 & 510 & 55.8 & 7.7 & 0.95 & 8.1 & 879 \\
\hline & 7 & 420 & 55.7 & 8.6 & 0.93 & 9.3 & 2178 \\
\hline \multirow[t]{2}{*}{ Least significant difference } & 4 & 120 & 7.3 & 0.8 & 0.09 & 1.1 & 867 \\
\hline & 7 & 120 & 6.0 & 0.6 & 0.06 & 0.8 & 529 \\
\hline
\end{tabular}

${ }^{\mathrm{z} F r u i t}$ samples collected on 25 Feb. 2000 (tree age 4 years) and 29 Jan. 2003 (age 7 years). Data are sorted by soluble solids (SS)/ha, tree age 7 years.

${ }^{y}$ Determined from the fruit sample collected for juice analysis.

${ }^{\mathrm{x}}$ Calculated as fruit yield per hectare $(\mathrm{wt}) \times \%$ juice $\times \mathrm{SS}$ concentration.

minimal and trees have sometimes yielded well for their size (Castle et al., 2010a), but at other times not so well as reported herein.

The citrumelo rootstock rankings were distributed throughout the list of rootstocks tested in E.1. Only one citrumelo rootstock, F80-9, appeared among the highest yielding rootstocks. In another trial with 'Marsh' grapefruit scion in a different coastal soil, the trees on F80-9 had above-average yield, but there were only small differences among various citrumelo rootstocks (Castle and Bauer, 2005). The trial trees were all eventually removed because of a decline associated with the soil series. A similar lack of large differences among citrumelo rootstocks was also the result in trials with 'Hamlin' and 'Valencia' sweet oranges in sites of coastal flatwoods soil series (Castle et al., 1988; Castle and Baldwin, 2008; Youtsey and Lee, 1995).

Comparative performance among the mandarin and mandarin hybrid rootstocks. Five mandarin rootstocks and two hybrids were tested in E.2. Among those rootstocks, tree survival ranged from a low of $75 \%$ (Changsha mandarin) to no tree loss (Sun Chu Sha mandarin and the two hybrids rootstocks: $\times 639$ and C-54). The cause of the losses among the trees on Changsha, Sunki or Cleopatra mandarins was not obvious as some trees declined and became unthrifty with thin canopies. Trees on mandarin rootstocks are affected by blight, but generally not until they are 10- to 15-years old (Castle, 1987). We have evaluated Cleopatra, Changsha, and Sunki mandarin rootstocks in other Florida trials with mixed survival results, but blight was not an issue in the trial reported herein (Castle et al., 2005; Castle and Bauer, 2005; Castle and Baldwin, 2010; Wheaton et al., 1991). The top performing rootstocks in E.2 were the hybrids, $\times 639$, C-54, and Sunki mandarin. There were few significant differences in yield and SS production among them, and they were generally different from those on the other mandarin rootstocks. What furthers distinguishes C-54 and Sunki mandarin is their relatively short tree height and high yields, a combination that makes them promising for use as rootstocks for grapefruit in higher density plantings.

Two of the remaining mandarin hybrids are the recently released USDA rootstocks, US-812 and 897 that were included in E.1. They offer meaningful advantages over other commercial rootstocks in Florida such as tolerance to poor site conditions and associated pests and diseases, and in the case of US-897, significant dwarfing of the scion that would allow substantially higher planting density and easier management and harvesting (Castle et al., 1993, 2006). US-812 is a
Sunki mandarin $\times$ Benecke TF hybrid and yielded just below what would be selected for the most promising group in these trials. The 7 -year-old trees on US-812 were mediumsized, produced high quality fruit, and yielded about $74 \%$ of the fruit and $86 \%$ of the SS per hectare of the top producing rootstock.

Comparative performance among sour orange and related rootstocks. Trees on sour orange, Chinotto sour orange, and four-purported hybrids (Smooth Flat Seville, Kinkoji, Goutou, and Zhuluan) were included in E.2 (Deng et al., 2008). The relatively poor survival of the trees on sour orange and Chinotto sour orange was the result of CTV as determined from the observations of classical stem pitting symptoms in the vicinity of the bud union. No losses occurred among the trees on the other rootstocks because of their reported tolerance to tristeza virus (Castle et al., 1992). In this group, the highest ranking rootstock for fruit yield was sour orange. The trees on sour orange and Chinotto sour orange exhibited typical traits, i.e., they grew well on the variable soils of the Florida coastal regions, were susceptible to tristeza virus and produced fruit with high SS concentrations as routinely reported in other work (Castle, 1987; McCollum et al., 2002; Wutscher, 1979). The trees on related rootstocks like Smooth Flat Seville and Goutou also exhibited those traits, but fruit quality was relatively low as experienced in other trials (Castle et al., 1992; McCollum et al., 2002). Thus, these rootstocks as a group generally produced high quality fruit, but did not have high overall rankings because of relatively low fruit yield.

Other rootstocks. Two Rangpur $\times$ Marks TF siblings, 1261 and 1262, were tested in E.1 and produced quite different results (Tables 2 , 4, and 6). The trees on 1262 performed poorly and declined early in the trial, which explains their low yields. Those on 1261 were of average height and were more productive in fruit yield and SS per hectare than those on many of the citrange and citrumelo rootstocks. The fruit yield and juice characteristics of the trees on Rangpur $\times$ Swingle TF hybrid were average among the rootstocks tested, but the trees were relatively tall making it less desirable for use in modern orchards. Therefore, the Rangpur $\times$ TF rootstocks are of limited commercial promise in Florida.

'Cipo' sweet orange was tested because of its unusual procumbent or weeping growth habit and the potential for that trait to be transmitted to the scion (Bowman, 1994, 1997). Sweet orange selections are frequently included in trials, but often are not among the top performers (Castle, 1987; Wutscher, 1979). The trees on 'Cipo' were of average height with no procumbent growth apparent and produced only $\approx 50 \%$ of the fruit yield and SS of those on the highest ranking rootstocks (Tables 4 and 6).

Promising rootstocks. In our trials, five rootstocks appeared to be exceptionally promising for growing grapefruit for the fresh market or processing on the basis of yield, juice quality, and moderate to smaller 
tree size. C-54, a Sunki mandarin $\times$ Swingle TF hybrid, was recently named 'Carpenter' by the University of California and described as producing a medium- to largesized tree with good yield (Kupper et al., 2010). Considering both trials, trees on that rootstock were the most productive for fruit yield and quantity of SS per hectare. A sibling rootstock, C-146, had similar characteristics along with the Sunki $\times$ Flying Dragon TF hybrid. C-22, another sibling to $\mathrm{C}-54$, performed well with red grapefruit in Texas (Louzada et al., 2008). Trees on C-35 citrange were also relatively short in tree height, but among the highest yielding, a desirable combination. We have included C-35 in other unreported trials with grapefruit scion where they performed as reported herein. In one of those trials, we measured the distribution of fruit sizes on whole-tree crops. The trees on C-35 citrange produced large, usually oblate-shaped fruit with smooth, thin peels.

Trees on $\times 639$, a hybrid of Cleopatra mandarin $\times$ Rubidoux $\mathrm{TF}$, produced $7 \%$ less fruit than C-54, but their quantities of SS per hectare at age 7 years were not different. $\times 639$ has been among the top three rootstocks in Florida nursery propagations in recent years for many of the common commercial citrus cultivars (Division Plant Industry, 2010). Trees on x639 were consistently good performers in trials with navel and common orange selections (Castle and Baldwin, 2005; Castle et al., 2000, 2010a).

Describing the rootstocks mentioned above as having exceptional promise is partly based on the magnitude of difference between them and the other rootstocks in both trials especially Swingle citrumelo. For example, the difference between the trees on C-146 and Swingle citrumelo in fruit yield was $30 \%$ and $55 \%$ in SS per hectare at age 7 years. Those on C-54 in E. 2 produced $31 \%$ more fruit than the trees on sour orange and $77 \%$ more SS per hectare. However, note that the trees on the high yielding rootstocks were also distinguished by their consistent performance over the 4-year-measurement period and steadily increasing yield in most instances. The yields of trees on other rootstocks also increased, but less so with some tendency toward alternate bearing. "Consistency" as a decision criterion in rootstock testing and as a social factor determining commercial potential is never mentioned in the citrus rootstock literature. However, it can be a particularly meaningful factor especially when taking into account soil variability (Castle, 2010; Castle and Baldwin, 2010). Furthermore, a complete assessment of rootstocks for grapefruit scions should include factors that are important considerations for fresh-market fruit that we did not measure such as fruit sizes for packing, fruit shape, and peel thickness.

Other rootstocks with promise. The trees on US-812 had similar characteristics to those on $\times 639$ in that their yield was among the highest and tree height was average. SS production when the trees were 7-years old was not different from the values of the trees on the Sunki $\times$ Swingle TF or Sunki $\times$ Flying Dragon TF hybrids or C-35. Also, evidence to date indicates US-812 would be a good choice for use in calcareous soils (Castle et al., 2006).

Predicting relative rootstock performance: Cumulative yield vs. annual yields. We have been proposing recently that citrus rootstock trials can be substantially completed within 7 to 8 years after planting (Castle et al., 2010a, 2010 b). In E.1, yield at age 4 years was wellcorrelated with cumulative yield $\left(r=0.58^{*}\right)$ and in subsequent individual years that relationship increased to $r=0.97^{* * *}$. Likewise in E.2, the highly significant correlation values changed from 0.84 to 0.94 . Thus, the yields of individual years were predictive of the cumulative yields. However, we recognize that while it is possible that the cumulative yield after 4 years of annual measurement may not relate well to yield in later years, our proposal has been validated where we measured yield over longer terms (Castle et al., 2010a, 2010b).

\section{Conclusions}

After growing trees for 7 years and measuring standard horticultural variables for the last 4 years of that period, two Sunki mandarin $\times$ Swingle TF hybrids $(\mathrm{C}-54$ and C-146), Sunki $\times$ Flying Dragon TF, C-35 citrange, and a Cleopatra mandarin $\times$ Rubidoux TF hybrid $(\times 639)$ were identified as the most promising rootstocks for grapefruit scions. That assessment applies to fruit grown for processing, but further trials are needed to determine fruit sizes and peel quality for a more complete assessment of their potential as rootstocks for growing fresh fruit. These five rootstocks are rated as most promising by comparison with the commercial standard rootstocks, Swingle citrumelo, sour orange, and Cleopatra mandarin and because of their potential for use in modern orchards planted at spacings closer than the tradition ones (Kupper et al., 1994). Furthermore, the relationships among rootstocks were established early in the trials. Data from the first cropping years were significantly correlated with the cumulative results supporting the contention that traditional long-term field trials for the collection of most horticultural data may not be necessary.

\section{Literature Cited}

Barry, G.H., W.S. Castle, and F.S. Davies. 2004 Soluble solids accumulation in 'Valencia' sweet orange as related to rootstock selection and fruit size. J. Amer. Soc. Hort. Sci. 129: 594-598.

Bauer, M., W.S. Castle, B.J. Boman, and T.A. Obreza. 2005. Economic longevity of citrus trees on Swingle citrumelo rootstock and their suitability for soils of the Indian River region. Proc. Fla. State Hort. Soc. 118:24-27.

Bauer, M., W.S. Castle, B.J. Boman, and T.A. Obreza. 2007. Field guide to soil identification for Florida's citrus-growing regions. Univ. Fla. Coop. Extension Publ. SP-362.
Bowman, K.D. 1994. 'Cipo' sweet orange and its unique growth habit. Fruit Var. J. 48(4):230-234.

Bowman, K.D. 1997. Inheritance of procumbent habit from 'Cipo' sweet orange in crosses with 'Clementine' mandarin. J. Amer. Soc. Hort. Sci. 122(3):360-367.

Cameron, J.W. and R.K. Soost. 1986. 'C35' and 'C32': Citrange rootstocks for citrus. HortScience 21:157-158.

Castle, W.S. 1987. Citrus rootstocks, p. 361-399. In: Rom R.C. and R.F. Carlson (eds.). Rootstocks for fruit crops. Wiley, Hoboken, NJ.

Castle, W.S. 2010. A career perspective on citrus rootstocks, their development, and commercialization. HortScience 45:1-5.

Castle, W.S. and J.C. Baldwin. 2005. Rootstock effects on 'Hamlin' and 'Valencia' orange trees growing at Central Ridge and flatwoods locations. Proc. Fla. State Hort. Soc. 118:4-14

Castle, W.S. and J.C. Baldwin. 2008. Tree survival, growth, and juice quality of early-season sweet orange selections on eight rootstocks in Immokalee. Proc. Fla. State Hort. Soc. 121:140-144.

Castle, W.S. and J.C. Baldwin. 2010. 'Parson Brown' sweet orange performance in a rootstock planting. Proc. Fla. State Hort. Soc. 123: (In press).

Castle, W.S. and M.G. Bauer. 2005. The 10-year performance and survival of 'Marsh' grapefruit trees on Sun Chu Sha mandarin and various citrumelo rootstocks on Riviera sand, depressional, an Alfisol. Proc. Fla. State Hort. Soc. 118:80-84.

Castle, W.S. and R.L. Phillips. 1980. Performance of 'Marsh' grapefruit and 'Valencia' orange trees on eighteen rootstocks in a closely spaced planting. J. Amer. Soc. Hort. Sci. 105:496-499.

Castle, W.S., J.C. Baldwin, and J.W. Grosser. 2000. Performance of 'Washington' navel orange trees in rootstock trials located in Lake and St. Lucie counties. Proc. Fla. State Hort. Soc. 113:106-111.

Castle, W.S., J.C. Baldwin, and R.P. Muraro. 2005. 'Hamlin' orange trees on Flying Dragon trifoliate orange, Changsha mandarin, or Koethen sweet orange $\times$ Rubidoux trifoliate orange citrange rootstock at three in-row spacings in a Flatwoods site. Proc. Fla. State Hort. Soc. 120: 92-96.

Castle, W.S., J.C. Baldwin, and R.P. Muraro. 2010a. Rootstocks and the performance and economic returns of 'Hamlin' sweet orange trees. HortScience 45:875-881.

Castle, W.S., J.C. Baldwin, R.P. Muraro, and R. Littell. 2010b. Performance of 'Valencia' sweet orange trees on 12 rootstocks at two locations and an economic interpretation as a basis for rootstock selection. HortScience 45: 523-533.

Castle, W.S., K.D. Bowman, J.H. Graham, Jr., and D.P.H. Tucker. 2006. Florida citrus rootstock selection guide. Univ. Fla. Coop. Extension Publ. SP-248.

Castle, W.S., R.R. Pelosi, C.O. Youtsey, F.G. Gmitter, Jr., R.F. Lee, C.A. Powell, and X. Hu. 1992. Rootstocks similar to sour orange for Florida citrus trees. Proc. Fla. State Hort. Soc. 105:56-60.

Castle, W.S., D.P.H. Tucker, A.H. Krezdorn, and C.O. Youtsey. 1993. Rootstocks for Florida, 2nd ed. Univ. Fla. Coop. Ext. Publ. SP-42.

Castle, W.S., H.K. Wutscher, C.O. Youtsey, and R.R. Pelosi. 1988. Citrumelos as rootstocks for Florida citrus. Proc. Fla. State Hort. Soc. 101:28-33.

Davies, F.S. and L.K. Jackson. 2009. Citrus growing in Florida, 5th Ed. Univ. Press Florida, Gainesville.

Deng, X., C. Peng, Z. Chen, Z. Deng, and J. Li. 2008. Citrus varieties in China. China Agric. Press. 
Division Plant Industry, Bureau Citrus Budwood Registration. 2010. Annual report. Fla. Dept. Agr. Consumer Serv., Tallahassee.

Fellers, P.F. 1990. Florida's juice standards for grades and their differences from United States standards for grades and United States Food and Drug Administration standards of identity. Proc. Fla. State Hort. Soc. 103:260-265.

Fla. Agric. Stat. Serv. 2010. Florida citrus statistics 2008-2009. Fla. Dept. Agric. Consumer Serv. and USDA Agric. Marketing Serv.

Kupper, R.S., C.T. Federici, and M.L. Roose. 2010. Citrus rootstock breeding and evaluation. Citrograph 1(6):30-36.

Kupper, R.S., M.L. Roose, M.L. Arpaia, and R. Neja. 1994. Rootstocks for desert grapefruit evaluated. California Grower 18:32-34.

Louzada, E.S., H.S. del Rio, M. Setamou, J.W. Watson, and D.M. Swietlik. 2008. Evaluation of citrus rootstocks for the high $\mathrm{pH}$, calcareous soils of South Texas. Euphytica 164:13-18.
McCollum, T.G., K.D. Bowman, and W.S. Castle. 2002. Effects of rootstock on fruit quality and postharvest behavior of 'Marsh' grapefruit. Proc. Fla. State Hort. Soc. 115:44-46.

McCoy, C.W., W.S. Castle, J.H. Graham, J.P. Syvertsen, and R.J. Stuart. 2004. Pesticide suppression of Diaprepes abbreviatus (L.) (Coleoptera: Curculionidae) promoted differential growth and survival of 'Hamlin' orange trees budded to five rootstocks in a Phytophthora infested grove. Proc. Fla. State Hort. Soc. 117:167-173.

Obreza, T.A. and K.T. Morgan (eds.). 2008. Nutrition of Florida citrus trees, 2nd edition. Univ. Fla. Coop. Ext. Publ. SL-253.

Rogers, M.E., M.M. Dewdney, and T.M. Spann (eds.). 2009. 2010 Florida citrus pest management guide. Univ. Fla. Cop. Ext. Publ. SP-43.

Roose, M.L. 1996. Performance of 4 citrus scions on 21 rootstocks in California. Proc. Intl. Soc. Citriculture 1:141-144.
Stover, E. and W. Castle. 2002. Citrus rootstock usage, characteristics, and selection in the Florida Indian River region. HortTechnology 12:143-147.

Wardowski, W., J. Whigham, W. Grierson and J. Soule. 1995. Quality tests for Florida citrus. Univ. Fl. Coop. Extension Bull. SP-99.

Wheaton, T.A., W.S. Castle, J.D. Whitney, and D.P.H. Tucker. 1991. Performance of citrus scion cultivars and rootstocks in a high density planting. HortScience 26:837-840.

Wutscher, H.K. 1979. Citrus rootstocks. Hort. Rev. $1: 237-269$.

Youtsey, C.O. and O. Lee. 1995. A 6-year comparison between 16 rootstocks budded with 'Hamlin' sweet orange. Proc. Fla. State Hort Soc. 108:69-73.

Zamski, E. and A.A. Schaffer. 1996. Photoassimilate distribution in plants and crops: Source-sink relationships. Marcel Dekker, New York. 